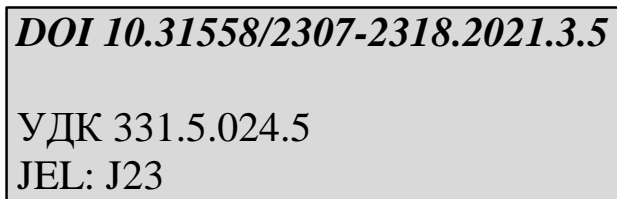

Бондаревська К.В.

доктор економічних наук, доцент, доцент кафедри економіки та управління національним господарством, Дніпровський національний університет імені Олеся Гончара

ORCID: 0000-0001-8683-6834

kseny-8888@i.ua

\title{
КЛЮЧОВІ ЗАГРОЗИ ТА ПЕРСПЕКТИВИ ПІТРИМКИ СОЦІАЛЬНОЇ БЕЗПЕКИ НА РИНКУ ПРАЦІ УКРАЇНИ
}

Статтю присвячено оцінці ключових загроз соціальній безпеці на ринку праџі України та визначенню перспектив їх нейтралізації в сучасних умовах. Наведено результати авторського експертного опитування «Загрози сочіальній безпеці на ринку прачі України та шляхи їх нейтралізащї». 3 урахуванням результатів дослідження визначено тенденції, які будуть відображати функціонування ринку праці України на перспективу найближчих 5-10 років. Обтрунтовано стратегічні пріоритети розвитку ринку прачі у контексті забезпечення його соціальної безпеки за категоріями безпеки зайнятості та безпеки оплати праці.

Ключові слова: соціальна безпека, ринок праці, зайнятість, оплата праці, загрози соиіальній безпеизі, безпека зайнятості, безпека оплати праџฺі.

Рис. - 2, Табл. - 7, Літ. - 12

Постановка проблеми. Процеси економічної трансформації, що відображають сучасний стан економічного середовища, викликають значні перетворення на ринку праці. Все це має своє вираження у появі нових та зміні традиційних професій, виникненні нестандартних форм зайнятості, зростанні масштабів структурного безробіття, формуванні нових якостей соціально-трудових відносин, орієнтованих на пріоритетність інноваційного розвитку та інформаційної складової. Трансформаційні зміни економіки формують значні ризики та загрози соціальній безпеці на ринку праці, зокрема у контексті поширення неформальної зайнятості, молодіжного безробіття, зниження рівня реальних доходів населення. Все це, у свою чергу, потребує глибокої та комплексної діагностики, що включатиме не лише визначення поточного стану загроз, а й висвітлення прогнозних їх характеристик з урахуванням можливостей коригування отриманих даних, що $є$ особливо важливим в умовах мінливості зовнішнього та внутрішнього економічного середовища.

Аналіз останніх досліджень і публікацій. Результати дослідження проблематики розвитку ринку праці та забезпечення соціальної безпеки знайшли своє відображення у наукових працях як зарубіжних, так і вітчизняних авторів. Серед робіт зарубіжних дослідників слід відмітити наукові праці Т. Вільгагена, К. Крауча, Б. Меніхерта, Г. Стендінга, у яких висвітлені концептуальні основи безпеки в контексті розвитку людського потенціалу та функціонування ринку праці [1-3]. Важливі аспекти розвитку ринку праці та забезпечення соціальної безпеки розкривають у своїх роботах вітчизняні 
дослідники О. Грішнова, О. Дороніна, Л. Лісогор, У. Садова, О. Сидорчук, Л. Шаульська та інші [4-8]. У той же час особливої актуальності наразі набуває необхідність актуалізації наявних загроз у сфері зайнятості та оплати праці, а також обгрунтування шляхів їх нейтралізації в сучасних умовах.

Формулювання цілей статті. Метою статті $є$ ідентифікація ключових загроз соціальній безпеці на ринку праці України та обгрунтування перспектив щодо їх нейтралізації.

Виклад основного матеріалу. На нашу думку, базовою складовою проведення оцінки ключових загроз соціальній безпеці на ринку праці $\epsilon$ визначення їх вираженості та напрямів нейтралізації з урахуванням думок експертів - провідних учених та практиків у сфері праці та зайнятості населення. Так, експертне оцінювання надає можливість отримати формалізований опис складних задач, вирішення яких неможливе із залученням лише статистичних методів дослідження на основі математичних моделей $[9$, с. 24]. Саме тому необхідною характеристикою експертного опитування $є$ залучення лише авторитетних спеціалістів, які мають значний професійний досвід як теоретичного, так і прикладного характеру, та можуть надати вичерпні відповіді на важливі питання щодо перспектив розвитку ринку праці, а також здійснити кількісне оцінювання вираженості ключових загроз і значущості факторів впливу на формування стану соціальної безпеки на ринку праці. В результаті застосування вищезазначеного методу діагностики загроз та перспектив розвитку ринку праці стає можливим отримання авторитетної та достовірної інформації, що дає можливість ii подальшого використання у наступних етапах оціночного механізму. 3 метою ефективного застосування експертного методу необхідним $\epsilon$ забезпечення успішного проходження кожного з його етапів, серед яких:

I. формування мети експертного опитування, вибір його структури (кількісної та якісної), характеристика об'єкта дослідження;

II. формулювання переліку питань, які відображають суть досліджуваного явища та забезпечують отримання інформації відповідно до поставленої мети (при цьому самі питання мають відповідати вимогам чіткості, однозначності та зрозумілості для респондентів);

III. технічна підготовка експертної анкети для різних способів проведення опитування (для зручності проведення анкети були підготовлені як для он-лайн, так і для офф-лайн форматів);

IV. пошук експертів та налагоджування зворотнього зв'язку (в тому числі отримання згоди на проходження опитування);

V. проведення експертного опитування (надання анкетного бланку експертам та отримання заповнених анкет);

VI. аналіз та обробка результатів експертного опитування (підведення підсумків бального оцінювання та обробка відповідей на відкриті запитання);

VII. оцінка перспектив впровадження результатів експертного опитування та міри досягнення поставленої мети.

Метою проведеного автором експертного опитування «Загрози соціальній безпеці на ринку праці України та шляхи їх нейтралізації» стало визначення загроз i обгрунтування напрямів подальшого розвитку ринку праці в контексті забезпечення соціальної безпеки на ньому. Респондентами були надані відповіді на запитання як відкритого, так і закритого характеру із використанням бальної оціночної шкали від 1 до 10 (де 1 бал є мінімальною, 10 балів є максимальною оцінкою) [10].

У процесі опитування експерти висловили власну думку стосовно таких питань, як: 
-оцінка ступеня значущості чинників, які у найбільшій мірі перешкоджають розвитку ринку праці в Україні;

-визначення ступеня вираженості загроз на ринку праці в Україні та світі, що будуть посилюватися у перспективі найближчих 5-10 років;

-визначення найбільш показових (значущих) індикаторів соціальної безпеки ринку праці;

-оцінка рівня соціальної безпеки на сучасному ринку праці України;

-характеристика найбільш суттєвих перешкод соціальній безпеці на ринку праці, які характерні для сучасного етапу його розвитку;

-оцінка напрямів скорочення неформальної зайнятості в Україні за ступенем їх важливості;

-оцінка напрямів стимулювання молодіжної зайнятості в Україні за ступенем їх впливу на ефективність ринку праці;

-оцінка напрямів удосконалення освітньої сфери, зокрема в контексті співпраці 3 бізнес-структурами, що покликані сприяти вирішенню проблеми молодіжної зайнятості в Україні;

-визначення першочергових умов розвитку нестандартних форм зайнятості в Україні (фрілансу, надомної роботи, тощо);

-визначення стратегічно важливих пріоритетів розвитку ринку праці в Україні;

-визначення як позитивних, так і негативних тенденцій розвитку ринку праці України, які будуть характерними для перспективи найближчих 5-10 років.

Таким чином, в ході проведення експертного опитування врахована необхідність проведення оцінки в рамках двох складових, що здійснюються в логічній послідовності: визначення ступеня вираженості ключових загроз на ринку праці, а також характеристику перспектив їх нейтралізації в сучасних умовах. При цьому оцінка перспектив базується на попередньо проведеному аналізі значимості загроз та чинників, які перешкоджають ефективному функціонуванню ринку праці в Україні.

Високий рівень професійної компетентності та значний досвід наукової $\mathrm{i}$ професійної діяльності експертів дозволив в повній мірі визначити та охарактеризувати найбільш суттєві загрози на ринку праці та визначити напрями їх нейтралізації. В експертному опитуванні, що було проведене у жовтні 2020 року, взяли участь 30 осіб, серед яких провідні вітчизняні науковці, які проводять грунтовні дослідження у сфері соціальної безпеки та розвитку ринку праці (53,3 \% представників освітніх закладів та 3,3 \% представників наукових установ); працівники органів державної влади та державної служби зайнятості як на національному, так і на регіональному рівнях (відповідно по 6,7\%); досвідчені й компетентні у питаннях праці та зайнятості працівники підприємств, організацій та установ із різних регіонів України $(26,7 \%)$, представники медіа $(3,3 \%)$. Відповідна структура сфер професійної діяльності залучених експертів наведена на рисунку 1.

Якісний склад учасників експертного опитування свідчить про участь у дослідженні як докторів, так і кандидатів наук (30\% та 36,7\% респондентів відповідно). Територіальний розподіл респондентів засвідчив наявність експертів з таких регіонів, як м. Київ, Дніпропетровська, Вінницька, Одеська, Полтавська, Запорізька, Волинська, Тернопільська, Черкаська області. 


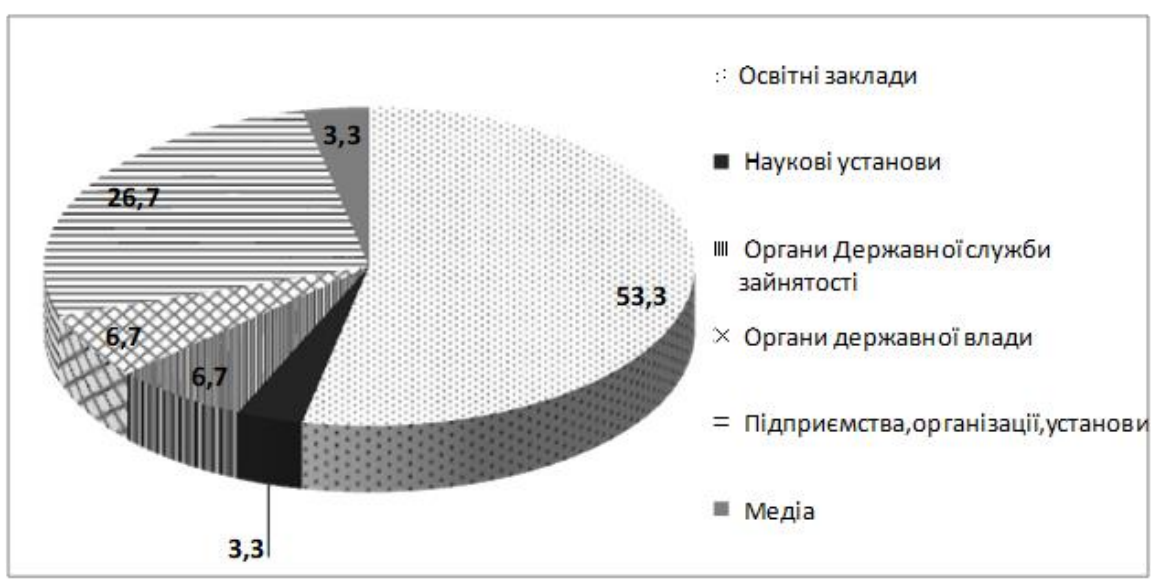

Рисунок 1. Розподіл експертів, залучених до дослідження «Загрози соціальній безпеці на ринку праці України та шляхи їх нейтралізації» за сферами професійної діяльності Джерело: розробка автора

У результаті експертного опитування визначено як конкретні перешкоди та загрози соціальній безпеці на ринку праці, так і перспективи усунення. Враховуючи структурнологічні особливості дослідження у якості першого етапу експертного опитування було проведено оцінку ступеня значущості чинників, які у найбільшій мірі перешкоджають розвитку ринку праці в Україні. Важливим в процесі характеристики основних перешкод розвитку ринку праці $\epsilon$ їх ранжування за рівнем отриманих експертних оцінок. Відповідні результати наведені у таблиці 1.

Таблиця 1. Чинники, що перешкоджають розвитку ринку праці в Україні та рівень їх значущості

\begin{tabular}{|c|c|c|c|}
\hline Чинники & $\begin{array}{c}\text { Сумарна } \\
\text { оцінка, } \\
\text { балів }\end{array}$ & $\begin{array}{c}\text { Середня } \\
\text { оцінка*, } \\
\text { балів }\end{array}$ & Ранг \\
\hline Низький рівень оплати праці & 214 & 7,13 & 1 \\
\hline $\begin{array}{l}\text { Неефективність макроекономічної політики держави, що негативно } \\
\text { впливає на загальну економічну ситуацію }\end{array}$ & 199 & 6,63 & 2 \\
\hline Поширення міграційних процесів & 187 & 6,23 & 3 \\
\hline Корупція & 185 & 6,17 & 4 \\
\hline Несприятливий інвестиційний клімат & 185 & 6,17 & 4 \\
\hline Неформальна зайнятість та тінізація заробітної плати & 182 & 6,07 & 5 \\
\hline $\begin{array}{lcc}\text { Невідповідність } & \text { освітньо-професійних } \\
\text { навчальних закладів потребам ринку праці } & \text { хактеристик } & \text { випускників } \\
\end{array}$ & 169 & 5,63 & 6 \\
\hline Неефективність державного регулювання ринку праці & 161 & 5,37 & 7 \\
\hline $\begin{array}{l}\text { Недосконалість законодавчої бази, що регулює соціально-трудові } \\
\text { відносини }\end{array}$ & 159 & 5,3 & 8 \\
\hline Невисока підприємницька активність & 158 & 5,27 & 9 \\
\hline
\end{tabular}

*максимальна оиінка - 10 балів.

Джерело: розробка автора на основі результатів експертного опитування

Згідно отриманого рангу було визначено три рівні значущості чинників:

- високий (із ранговими значеннями від 1 до 3),

- середній (із значеннями рангу від 4 до 6),

- низький (із ранговими значеннями від 7 до 9).

Відтак, до чинників, які в найбільшій мірі перешкоджають розвитку ринку праці, було віднесено: низький рівень оплати праці; неефективність макроекономічної політики 
держави, яка негативно впливає на загальну економічну ситуацію; поширення міграційних процесів. Саме ці перешкоди були визначені експертами у якості першочергових чинників впливу на ринок праці та отримали високі бальні оцінки. Середній рівень значущості засвідчили такі чинники, як: корупція та несприятливий інвестиційний клімат (з однаковими значеннями бальних оцінок), неформальна зайнятість та тінізація оплати праці, а також невідповідність освітньо-професійних характеристик випускників навчальних закладів потребам ринку праці (значення відповідних рангів були зафіксовані у межах від 4 до 6). В свою чергу несуттєвий вплив на ринок праці здійснюють такі чинники, як: недостатня ефективність державного регулювання ринку праці, недосконалість законодавчої бази щодо регулювання соціально-трудових відносин та невисока підприємницька активність.

3 метою характеристики низького, середнього та високого ступенів вираженості загроз на ринку праці в Україні та світі було визначено відповідні рангові значення за результатами експертного оцінювання (табл. 2).

Таблиця 2. Загрози на ринку праці в Україні та світі, що будуть посилюватися у перспективі найближчих 5-10 років, та ступінь їх вираженості

\begin{tabular}{|c|c|c|c|c|c|c|}
\hline \multirow[b]{2}{*}{ Загрози } & \multicolumn{2}{|c|}{ Україна } & \multirow[b]{2}{*}{ Ранг } & \multicolumn{2}{|c|}{ Cвiт } & \multirow[b]{2}{*}{ Ранг } \\
\hline & $\begin{array}{l}\text { сумарна } \\
\text { оцінка, } \\
\text { балів }\end{array}$ & $\begin{array}{c}\text { середня } \\
\text { оцінка*, } \\
\text { балів }\end{array}$ & & $\begin{array}{l}\text { сумарна } \\
\text { оцінка, } \\
\text { балів }\end{array}$ & $\begin{array}{c}\text { середня } \\
\text { оцінка*, } \\
\text { балів }\end{array}$ & \\
\hline $\begin{array}{l}\text { Економічні кризи на глобальному } \\
\text { національному рівнях }\end{array}$ & 212 & 7,07 & 1 & 203 & 6,77 & 2 \\
\hline Зростання рівня молодіжного безробіття & 208 & 6,93 & 2 & 179 & 5,97 & 5 \\
\hline Поширення міграційних процесів & 205 & 6,83 & 3 & 200 & 6,67 & 3 \\
\hline $\begin{array}{lll}\text { Зниження } \\
\text { населення }\end{array}$ & 204 & 6,8 & 4 & 179 & 5,97 & 5 \\
\hline $\begin{array}{llr}\text { Неврегульованість нестандартних } & \text { форм } \\
\text { зайнятості (фріланс, } & \text { надомна } \\
\text { дистанційна робота тощо) } & & \\
\end{array}$ & 201 & 6,7 & 5 & 184 & 6,13 & 4 \\
\hline Зростання рівня безробіття & 190 & 6,33 & 6 & 176 & 5,87 & 6 \\
\hline Зростання неформальної зайнятості & 175 & 5,83 & 7 & 174 & 5,8 & 7 \\
\hline $\begin{array}{l}\text { Неефективність державного регулювання } \\
\text { ринку праці }\end{array}$ & 175 & 5,83 & 7 & 163 & 5,43 & 9 \\
\hline $\begin{array}{l}\text { Вихід } 3 \text { ринку праці осіб старшого віку } \\
\text { (звільнення, добровільний вихід на пенсію, } \\
\text { дискримінаційні прояви тощо) }\end{array}$ & 172 & 5,73 & 8 & 165 & 5,5 & 8 \\
\hline Діджиталізація та інформатизація & 170 & 5,67 & 9 & 206 & 6,87 & 1 \\
\hline
\end{tabular}

*максимальна оиінка - 10 балів.

Джерело: розробка автора на основі результатів експертного опитування

В ході порівняльного аналізу отриманих результатів спостерігаються суттєві відмінності у національних та світових тенденціях посилення загроз: якщо в Україні у перспективі найближчих 5-10 років із високою ймовірністю очікується зростання впливу економічних криз як на глобальному, так і на національному рівнях; то у світі ця загроза знаходиться на останньому місці за своєю вираженістю [11, С.17].

У той же час на першу позицію за впливом на світовий ринок праці виходять загрози, пов'язані з діджиталізацією та інформатизацією. Зокрема, це стосується динамічної цифрової трансформації суспільства, що відображається і на соціальнотрудовій сфери, кидаючи виклик традиційним професіям та потребуючи формування нових навичок роботи та високої конкурентоспроможності робочої сили. Все це визначає 
посилення ролі розвитку працівників та впровадження концепції навчання впродовж життя, високої адаптивності до змін та мобільності у професійній сфері.

Окрім впливу економічних криз серед загроз на ринку праці найближчих 5-10 років в Україні слід відзначити високу ступінь вираженості загрози зростання молодіжного безробіття та поширення міграційних процесів. У порівнянні із світовими тенденціями, простежуються схожі риси відносно посилення міграційних процесів (3 позиція) та економічних криз (2 позиція). Дещо краща ситуація у світі очікується стосовно зростання молодіжного безробіття (5 ранг в світі у порівнянні з 2 рангом в Україні). Схожі риси середньої вираженості загроз на ринку праці в Україні та світі простежуються відносно зниження рівня реальних доходів населення (4 та 5 ранг відповідно), неврегульованості нестандартних форм зайнятості (5 та 4 ранг відповідно), зростання рівня безробіття (6 ранг). Незначний рівень посилення загроз на національному ринку праці у найближчі 510 років очікується щодо зростання неформальної зайнятості; наслідків неефективного державного регулювання ринку праці; проблем, пов'язаних із виходом з ринку праці осіб старшого віку (зокрема, дискримінацій в процесі трудової діяльності та при звільненні, що суперечить визнаній у світі концепції активного старіння); наслідків діджиталізації та інформатизації. На світовому ринку праці передбачається незначне поширення неформальної зайнятості та проблем на ринку праці для осіб старшого віку. Наслідки неефективного державного регулювання сфери праці та зайнятості у світі, на думку експертів, є несуттєвими.

Оцінка перешкод розвитку ринку праці та прогнозування вираженості відповідних загроз надає можливість визначення найбільш значущих індикаторів соціальної безпеки ринку праці (табл. 3).

Таблиця 3. Результати визначення найбільш значущих індикаторів соціальної безпеки на ринку праці України

\begin{tabular}{|l|l|l|}
\hline \multicolumn{1}{|c|}{ Індикатор } & $\begin{array}{c}\text { Кількість } \\
\text { експертів } \\
(\%)\end{array}$ & $\begin{array}{c}\text { Сфера соціальної безпеки } \\
\text { на ринку праці }\end{array}$ \\
\hline Рівень зайнятості & 10,0 & Безпека зайнятості \\
\hline Рівень економічної активності & 3,3 & Безпека зайнятості \\
\hline Рівень безробіття & 26,7 & Безпека зайнятості \\
\hline Рівень молодіжного безробіття & 13,3 & Безпека зайнятості \\
\hline $\begin{array}{l}\text { Рівень безробіття серед осіб, наближених до пенсійного } \\
\text { віку }\end{array}$ & 3,3 & Безпека зайнятості \\
\hline Відсоток працюючих осіб пенсійного віку & 6,7 & Безпека зайнятості \\
\hline Рівень працевлаштування незайнятих громадян & 3,3 & Безпека зайнятості \\
\hline Навантаження на одне вільне робоче місце & 6,7 & Безпека зайнятості \\
\hline Кількість громадян, які виїжджають на роботу за кордон & 6,7 & Безпека зайнятості \\
\hline Рівень тіньової (неформальної) зайнятості & 16,7 & Безпека зайнятості \\
\hline Середня заробітна плата & 20,0 & Безпека оплати праці \\
\hline Реальна заробітна плата & 6,7 & Безпека оплати праці \\
\hline $\begin{array}{l}\text { Співвідношення середньої зарплати і прожиткового } \\
\text { мінімуму }\end{array}$ & 6,7 & Безпека оплати праці \\
\hline Співвідношення середньої та мінімальної заробітної плати & 6,7 & Безпека оплати праці \\
\hline $\begin{array}{l}\text { Частка працівників, які отримують зарплату нижче } \\
\text { середнього рівня }\end{array}$ & 3,3 & Безпека оплати праці \\
\hline Частка працівників, які отримують мінімальну зарплату & 3,3 & Безпека оплати праці \\
\hline Рівень доходів населення & 16,7 & Безпека оплати праці \\
\hline Рівень бідності & 10,0 & Безпека оплати праці \\
\hline
\end{tabular}

Джерело: розробка автора на основі результатів експертного опитування 
Так, більшість експертів, що взяли участь в опитуванні, у якості провідних індикаторів соціальної безпеки на ринку праці визначили рівень безробіття $(26,7$ \% респондентів), середню заробітну плату (20\%), рівень неформальної зайнятості $(16,7 \%)$, рівень доходів населення (16,7\%). До загального переліку індикаторів, визначених експертами, належали 18 показників, серед яких ті, що засвідчують стан як сфери безпеки зайнятості, так і сфери безпеки оплати праці.

Враховуючи особливості сучасного стану сфери праці та зайнятості в Україні, зокрема наявність суттєвих загроз та перешкод іï розвитку, 60 \% опитаних експертів висловили думку щодо низького рівня соціальної безпеки на ринку праці (рис. 2).

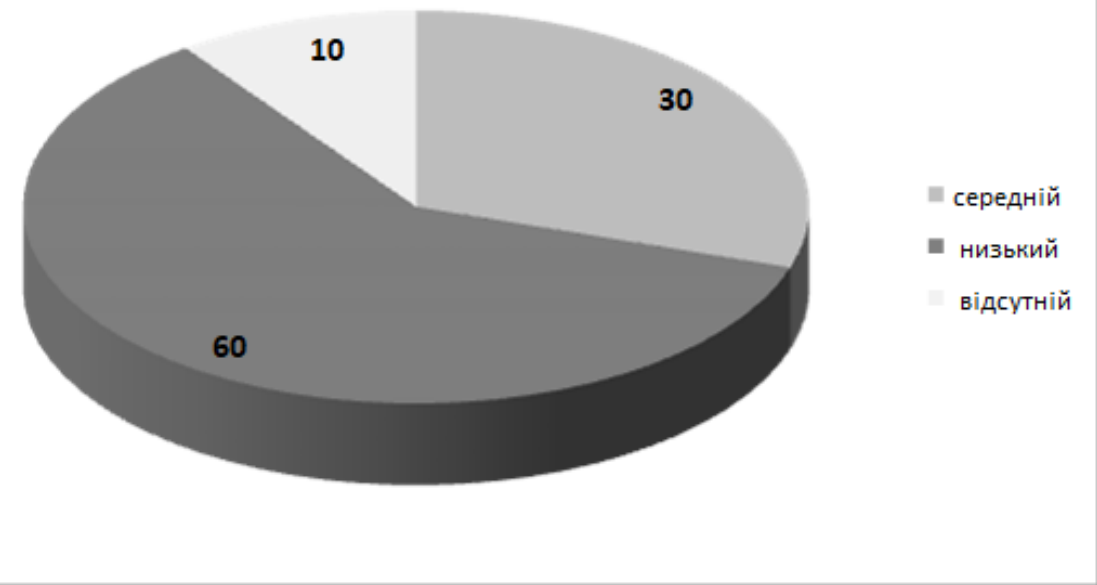

Рисунок 2. Експертна оцінка рівня соціальної безпеки на ринку праці України, \% Джерело: розробка автора на основі результатів експертного опитування

Ще $30 \%$ респондентів вважають, що рівень соціальної безпеки на ринку праці наразі $\epsilon$ середнім, $10 \%$ опитаних експертів відзначили повну відсутність стану соціальної безпеки на ринку праці України взагалі. Все це засвідчує наявність суттєвих проблем у формуванні стану захищеності соціальних інтересів населення України на ринку праці та низьку ефективність соціально-трудових відносин як на рівні держави, регіонів, суб'єктів господарювання, так і на рівні індивіда.

Серед найбільш значних перешкод соціальній безпеці на ринку праці, були визначені: тінізація зайнятості (30\% опитаних), зростання безробіття, в тому числі молодіжного $(20 \%)$, неефективність державного регулювання зайнятості та макроекономічної політики в країні (20 \%), невідповідність сфери освіти потребам ринку праці та низький рівень розвитку й підтримки підприємництва (відповідно по 16,7 \% опитаних), посилення міграційних процесів (16,7\%). Дещо менша частка опитаних експертів висловила думку стосовно наявності таких перешкод, як недостатня кількість робочих місць 3 ринковою оплатою $(13,3 \%)$, корупція та тінізація оплати праці (відповідно по 10 \% опитаних), низький рівень встановлених соціальних гарантій (10\%), неврегульованість нестандартних форм зайнятості (3,3\%). Окрім вищенаведених перешкод на шляху забезпечення соціальної безпеки на ринку праці України було відзначено високу ступінь бюрократизації соціально-трудових відносин, прагнення роботодавців до економії витрат на персонал та першочергової максимізації прибутку поряд із необізнаністю працівників зі своїми правами у сфері праці та зайнятості. Результати експертного опитування стосовно цього питання наведені у таблиці 4. 
Таблиця 4. Результати визначення найбільш суттєвих перешкод соціальній безпеці на ринку праці України

\begin{tabular}{|c|c|c|}
\hline Перешкоди & $\begin{array}{l}\text { Кількість } \\
\text { експертів } \\
\quad(\%)\end{array}$ & $\begin{array}{l}\text { Сфера соціальної } \\
\text { безпеки на ринку } \\
\text { праці }\end{array}$ \\
\hline Тінізація зайнятості & 30,0 & Безпека зайнятості \\
\hline Зростання безробіття, в тому числі молоді & 20,0 & Безпека зайнятості \\
\hline $\begin{array}{llc}\text { Неефективність } & \text { державного } & \text { регулювання } \\
\text { зайнятості та макроекономічної політики в країні }\end{array}$ & 20,0 & $\begin{array}{l}\text { Безпека зайнятості, } \\
\text { безпека оплати праці }\end{array}$ \\
\hline Зниження рівня реальних трудових доходів & 20,0 & Безпека оплати праці \\
\hline $\begin{array}{l}\text { Збільшення масштабів міграції кваліфікованої } \\
\text { робочої сили }\end{array}$ & 16,7 & Безпека зайнятості \\
\hline $\begin{array}{l}\text { Невідповідність освіти потребам ринку праці та } \\
\text { професійно-кваліфікаційний дисбаланс на ринку } \\
\text { праці }\end{array}$ & 16,7 & Безпека зайнятості \\
\hline $\begin{array}{l}\text { Низький рівень підтримки підприємництва та } \\
\text { інвестиційної активності }\end{array}$ & 16,7 & $\begin{array}{c}\text { Безпека зайнятості } \\
\text { Безпека оплати праці }\end{array}$ \\
\hline $\begin{array}{l}\text { Недостатня кількість робочих місць } 3 \text { ринковою } \\
\text { оплатою праці }\end{array}$ & 13,3 & $\begin{array}{c}\text { Безпека зайнятості } \\
\text { Безпека оплати праці }\end{array}$ \\
\hline Корупція & 10,0 & $\begin{array}{c}\text { Безпека зайнятості } \\
\text { Безпека оплати праці }\end{array}$ \\
\hline Тінізація оплати праці & 10,0 & Безпека оплати праці \\
\hline $\begin{array}{l}\text { Низький рівень встановлених соціальних } \\
\text { гарантій }\end{array}$ & 10,0 & Безпека оплати праці \\
\hline $\begin{array}{ll}\text { Неврегульованість } & \text { нестандартних } \\
\text { зайнятості } & \\
\end{array}$ & 3,3 & Безпека зайнятості \\
\hline
\end{tabular}

Джерело: розробка автора на основі результатів експертного опитування

Враховуючи думку провідних вчених, фахівців у сфері праці та зайнятості населення, працівників органів державної влади та ДСЗ України, слід зазначити важливість усунення суттєвих перешкод, які в найбільшій мірі перешкоджають забезпеченню соціальної безпеки на ринку праці. Це стосується необхідності скорочення масштабів неформальної зайнятості, зниження рівня безробіття, підвищення реальних доходів населення, зокрема за рахунок зростання заробітної плати та встановлення справедливої іiі диференціації, що передбачає врахування освітньо-кваліфікаційних якостей, трудового внеску, складності роботи та її умов на основі дотримання принципу соціальної справедливості. При цьому слід відзначити схожість експертних висновків та авторської думки відносно ключових загроз соціальній безпеці на ринку праці, які включають наслідки неформальної зайнятості, молодіжного безробіття та низького рівня оплати праці. Нейтралізація першочергових перешкод забезпечення соціальної безпеки на ринку праці передбачена у якості основоположного пріоритету відповідної багаторівневої стратегії, яка направлена на активізацію безпекових механізмів у сфері зайнятості та оплати праці.

Саме оцінці перспектив нейтралізації загроз соціальній безпеці на ринку праці присвячено другий блок експертного опитування. За результатами оцінки напрямів скорочення неформальної зайнятості в Україні було враховано розподіл рангів на групи високого (від 1 до 3), середнього (від 4 до 7) та низького (від 8 до 10) ступенів важливості 
та величини впливу на розвиток вітчизняного ринку праці. Результати експертного оцінювання по даному питанню, а також присвоєні ранги, наведено у таблиці 5.

Таблиця 5. Результати оцінки напрямів скорочення неформальної зайнятості в Україні

\begin{tabular}{|c|c|c|c|}
\hline Напрями & $\begin{array}{c}\text { Сумарна } \\
\text { оцінка, } \\
\text { балів } \\
\end{array}$ & $\begin{array}{c}\text { Середня } \\
\text { оцінка*, } \\
\text { балів } \\
\end{array}$ & Ранг \\
\hline Підвищення рівня реальних доходів населення & 223 & 7,43 & 1 \\
\hline Справедлива диференціація оплати праці & 221 & 7,37 & 2 \\
\hline $\begin{array}{l}\text { Стимулювання розвитку малого та середнього бізнесу за допомогою } \\
\text { пільгового оподаткування та кредитування }\end{array}$ & 216 & 7,2 & 3 \\
\hline $\begin{array}{l}\text { Розвиток молодіжного підприємництва (пільгове оподаткування та } \\
\text { кредитування, інформаційна підтримка) }\end{array}$ & 208 & 6,93 & 4 \\
\hline $\begin{array}{l}\text { Стимулювання переходу працівників із неформального сектору до } \\
\text { формального за рахунок розвитку інноваційних форм зайнятості та } \\
\text { самозайнятості населення }\end{array}$ & 205 & 6,83 & 5 \\
\hline Підвищення якості адміністрування податків і соціальних внесків & 184 & 6,13 & 6 \\
\hline $\begin{array}{llll}\text { Удосконалення професійних стандартів підготовки } & \text { фахівців та } \\
\text { взаємодія з освітніми закладами } & & \\
\end{array}$ & 183 & 6,1 & 7 \\
\hline $\begin{array}{l}\text { Удосконалення системи пенсійного страхування, розвиток різних } \\
\text { форм соціального страхування }\end{array}$ & 182 & 6,07 & 8 \\
\hline $\begin{array}{l}\text { Інформаційна та консультаційна допомога малому та середньому } \\
\text { бізнесу }\end{array}$ & 181 & 6,03 & 9 \\
\hline Посилення контролю та санкцій з боку державних органів & 153 & 5,1 & 10 \\
\hline
\end{tabular}

*максимальна оцінка - 10 балів.

Джерело: розробка автора на основі результатів експертного опитування

Так, серед найбільш дієвих та важливих напрямів щодо зниження рівня неформальної зайнятості було визначено підвищення рівня реальних доходів населення, справедливу диференціацію оплати праці, а також стимулювання розвитку малого та середнього бізнесу за допомогою податкових пільг та сприятливих умов кредитування (відповідно 1, 2 та 3 ранги). Такі результати засвідчують значну роль ефективної організації оплати праці та необхідність іiі реформування як першочергового напряму, який сприятиме формалізації відносин зайнятості в Україні.

Забезпеченню розвитку формальних соціально-трудових відносин сприятиме також розвиток молодіжного підприємництва за рахунок активних заходів з боку держави стосовно удосконалення податкової та грошово-кредитної політики в контексті їх орієнтації на спрощені, пільгові умови у випадку заснування бізнесу молодою особою. Важливим $\epsilon$ також надання інформаційно-консультаційної підтримки для молоді стосовно особливостей реєстрації та ведення бізнесу. Переходу працівників із неформального сектору до формального буде сприяти й використання нестандартних форм зайнятості та самозайнятості населення, а також покращення якості та посилення контролю в процесі адміністрування податків і соціальних внесків. Рівень дієвості вищенаведених заходів був охарактеризований експертами бальними оцінками у межах від 6,1 до 6,93 середніх балів, що відповідає 4, 5, 6 та 7 рангам.

У свою чергу заходи, спрямовані на реформування системи пенсійного забезпечення та розвиток інших форм соціального страхування, не є провідними у переліку напрямів скорочення неформальної зайнятості. Схожим рівнем експертних оцінок відзначилися інформаційно-консультаційні заходи щодо розвитку малого та 
середнього бізнесу, а також посилення контролю та санкцій з боку органів державної влади, спрямованих на запобігання поширенню неформальної зайнятості.

Першочерговим заходам щодо нейтралізації загрози зростання молодіжного безробіття була присвячена оцінка напрямів стимулювання молодіжної зайнятості в Україні відповідно до ступеня їх впливу на ефективність ринку праці (табл. 6).

Таблиця 6. Результати оцінки напрямів стимулювання молодіжної зайнятості в Україні за ступенем їх впливу на ефективність ринку праці

\begin{tabular}{|l|c|c|c|}
\hline \multicolumn{1}{|c|}{ Напрями } & $\begin{array}{c}\text { Сумарна } \\
\text { оцінка, } \\
\text { балів }\end{array}$ & $\begin{array}{c}\text { Середня } \\
\text { оцінка*, } \\
\text { балів }\end{array}$ & Paнг \\
\hline Розвиток молодіжного підприємництва та стартапів & 222 & 7,4 & 1 \\
\hline $\begin{array}{l}\text { Розвиток системи наставництва та професійного коучингу } \\
\text { для молоді на рівні підприємств }\end{array}$ & 218 & 7,27 & 2 \\
\hline $\begin{array}{l}\text { Податкове птимулювання підприємств, які } \\
\text { працевлаштовують молодь }\end{array}$ & 210 & 7,0 & 3 \\
\hline $\begin{array}{l}\text { Співпраця закладів освіти та бізнес-структур в процесі } \\
\text { навчання: проведення спільних навчальних і практичних } \\
\text { заходів }\end{array}$ & 203 & 6,77 & 4 \\
\hline Посилення профорієнтаційної роботи серед молоді & 202 & 6,73 & 5 \\
\hline Впровадження дуальної освіти & 188 & 6,27 & 6 \\
\hline $\begin{array}{l}\text { Співпраця закладів освіти, організацій роботодавців, } \\
\text { профспілок, громадських організацій: проведення спільних } \\
\text { навчальних і практичних заходів }\end{array}$ & 186 & 6,2 & 7 \\
\hline $\begin{array}{l}\text { Законодавчі та адміністративні заходи з боку держави щодо } \\
\text { обов'язкового працевлаштування вразливих на ринку праці } \\
\text { категорій населення, в тому числі молоді }\end{array}$ & 172 & 5,73 & 8 \\
\hline $\begin{array}{l}\text { Інформування молоді щодо реального стану ринку праці та } \\
\text { функціонування бізнес-сфери }\end{array}$ & 170 & 5,67 & 9 \\
\hline $\begin{array}{l}\text { Співпраця закладів освіти та органів Державної служби } \\
\text { зайнятості: проведення спільних навчальних і практичних } \\
\text { заходів }\end{array}$ & 160 & 5,33 & 10 \\
\hline
\end{tabular}

*максимальна оиінка - 10 балів.

Джерело: розробка автора на основі результатів експертного опитування

Так, до найбільш впливових та значущих напрямів слід віднести розвиток молодіжного підприємництва та стартапів; розвиток системи наставництва та професійного коучингу для молоді на рівні підприємств; податкове стимулювання підприємств, які працевлаштовують молодь. Відповідні заходи сприятимуть всебічній реалізації трудового потенціалу молоді та підвищенню іiі конкурентоспроможності на ринку праці не лише в процесі провадження трудової діяльності в рамках підприємств, організацій та установ, а й у випадку заснування власного бізнесу. Держава, у свою чергу, здійснюватиме підтримку молодіжної зайнятості за допомогою податкових пільг для підприємств, які надають робочі місця молоді (зокрема, забезпечують випускників навчальних закладів першим місцем роботи), а також пільгового оподаткування новостворених підприємств на перші два роки свого функціонування (за аналогією позитивного досвіду економічно розвинених країн світу). 
Серед напрямів середнього рівня впливу на молодіжну зайнятість відзначилися навчальні та профорієнтаційні заходи, які забезпечують взаємодію освітньої сфери із бізнес-структурами, представницькими органами роботодавців та найманих працівників на ринку праці тощо. Зокрема, це: проведення навчальних та практичних заходів закладами освіти спільно із представниками бізнесу; посилення профорієнтаційної роботи серед молоді; запровадження дуальної освіти; проведення навчальних та практичних заходів закладами освіти спільно із такими суб'єктами регулювання ринку праці, як об'єднання роботодавців, профспілки та зацікавлені громадські організації. У практиці забезпечення співробітництва держави, сфер освіти та бізнесу відповідні напрями щодо сприяння молодіжній зайнятості частково впроваджуються у життя. Так, у 2017-2018 навчальному році був покладений початок впровадження елементів дуальної форми здобуття освіти у 52 закладах професійної (професійно-технічної) освіти у 25 регіонах України за 54 професіями. Згідно Розпорядження Кабінету Міністрів України від 19.09.2018 p. № 660-Р «Про схвалення Концепції підготовки фахівців за дуальною формою здобуття освіти» впровадження дуальної освіти має здійснюватися за наступними етапами: I етап - розробка нормативно-правової бази (2018-2019рр.); II етап - розробка типових моделей дуальної форми здобуття освіти у закладах освіти, реалізація пілотних проектів моделей дуальної форми здобуття освіти, проведення оцінки ефективності (20192020 роки); III етап - створення кластерів дуальної освіти на базі конкурентоспроможних закладів освіти та зацікавлених роботодавців (2020-2023 рр.) [12]. Таким чином, наразі досить успішно триває другий етап впровадження дуальної форми здобуття освіти, що виражається у врахуванні вимог роботодавців при формуванні змісту освітніх програм та графіка навчального-виробничого процесу в рамках тісної співпраці щодо впровадження основних елементів дуального навчання за структурним розподілом часу на теоретичне навчання в обсязі $30 \%$, навчання на виробництві - 70 \% годин. Профорієнтаційна робота серед молоді та практика проведення спільних навчальних і практичних занять в межах традиційного для України освітнього процесу ще потребує свого поширення.

Незначний, на думку експертів, вплив на стимулювання молодіжної зайнятості здійснюватимуть законодавчі та адміністративні заходи 3 боку держави щодо обов'язкового працевлаштування молоді; інформування молоді щодо реального стану ринку праці та функціонування бізнес-сфери, а також співпраця закладів освіти та органів Державної служби зайнятості в рамках проведення спільних навчальних i практичних заходів.

Враховуючи важливість удосконалення освітньої сфери, яка здійснює безпосередній вплив на покращення стану молодіжного сегменту ринку праці, необхідним $є$ визначення ступеня важливості відповідних заходів (табл. 7).

Таблиця 7. Результати оцінки напрямів удосконалення освітньої сфери, зокрема в контексті співпраці з бізнес-структурами, за ступенем їх важливості

\begin{tabular}{|c|c|c|c|}
\hline Напрями & $\begin{array}{c}\text { Сумарна } \\
\text { оцінка, } \\
\text { балів } \\
\end{array}$ & $\begin{array}{l}\text { Середня } \\
\text { оцінка*, } \\
\text { балів }\end{array}$ & Ранг \\
\hline 1 & 2 & 3 & 4 \\
\hline $\begin{array}{l}\text { Проведення спільних } 3 \text { представниками підприємств } \\
\text { навчальних занять та виробництві (на базі підприємств) }\end{array}$ & 217 & 7,23 & 1 \\
\hline 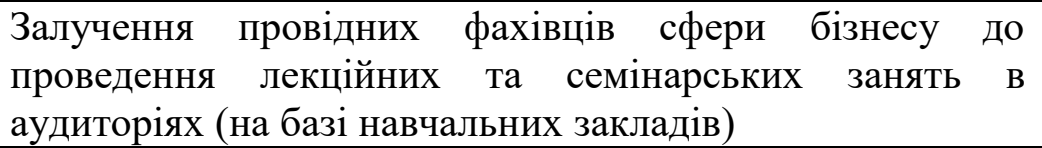 & 207 & 6,9 & 2 \\
\hline
\end{tabular}


Продовження таблиці 7

\begin{tabular}{|l|c|c|c|}
\hline \multicolumn{1}{|c|}{1} & 2 & 3 & 4 \\
\hline $\begin{array}{l}\text { Спільне заснування шкіл стартапів та шкіл молодого } \\
\text { підприємця }\end{array}$ & 207 & 6,9 & 2 \\
\hline $\begin{array}{l}\text { Удсконалення методики викладання навчальних } \\
\text { дисциплін, що забезпечить поєднання практичними } \\
\text { реаліями та більшу зацікавленість у вивченні матеріалу }\end{array}$ & 206 & 6,87 & 3 \\
\hline $\begin{array}{l}\text { Оновлення матеріально-технічної бази навчальних } \\
\text { закладів }\end{array}$ & 203 & 6,77 & 4 \\
\hline $\begin{array}{l}\text { Набуття практичного досвіду роботи в процесі навчання } \\
\text { узакладах освіти (наприклад, дуальна освіта) }\end{array}$ & 198 & 6,6 & 5 \\
\hline $\begin{array}{l}\text { Виконання науково-дослідних проектів студентами, } \\
\text { викладачами та науковцями на замовлення підприємств }\end{array}$ & 188 & 6,27 & 6 \\
\hline $\begin{array}{l}\text { Проведення конкурсів на кращу науково-практичну } \\
\text { розробку студентів за заохочення з боку підприємств, в } \\
\text { тому числі можливість стажування та (або) } \\
\text { працевлаштування }\end{array}$ & 188 & 6,27 & 6 \\
\hline $\begin{array}{l}\text { Моніторинг працевлаштування випускників закладів } \\
\text { освіти та створення інформаційної бази випускників }\end{array}$ & 187 & 6,23 & 7 \\
\hline $\begin{array}{l}\text { Розширення переліку баз виробничої та переддипломної } \\
\text { практик для студентів }\end{array}$ & 170 & 5,67 & 8 \\
\hline
\end{tabular}

*максимальна оиінка - 10 балів.

Джерело: розробка автора на основі результатів експертного опитування

Для конкретизації експертних оцінок відповідно до встановлених рангів було застосовано поділ рівня важливості на високий (1-3 ранги), середній (4-6 ранги), низький (7-8 ранги). За результатами оцінки напрямів покращення функціонування сфери освіти в контексті їх співпраці із бізнес-структурами серед пріоритетних було визначено проведення спільних з представниками підприємств навчальних занять як безпосередньо у виробничих умовах, так і на базі закладів освіти; формування шкіл стартапів та шкіл молодого підприємця спільними зусиллями представників сфер освіти та бізнесу; посилення практичної складової навчального матеріалу в процесі викладання (застосування практичних завдань із реальними прикладами підприємств, що сприятиме не лише формуванню необхідних в сучасних умовах практичних навичок роботи 3 конкретними даними, а й підвищенню зацікавленості у вивченні матеріалу зі сторони здобувачів освіти).

Важливими складовими удосконалення функціонування сфери освіти, спрямованими на покращення іiі взаємодії із бізнес-сферою, також $є$ : оновлення матеріально-технічної бази навчальних закладів, що забезпечуватиме широкі можливості використання сучасного обладнання з метою візуалізації та роботи 3 реальними об'єктами у межах навчальних аудиторій та лабораторій; дуальна освіта; виконання викладачами та студентами спільних науково-практичних розробок та проектів на замовлення роботодавців відповідно до їх нагальних потреб; а також проведення конкурсів на кращий проект з урахуванням заохочення як матеріального, так i нематеріального характеру (до останнього варто віднести надання переможцям 
можливості щодо стажування та (або) працевлаштування на підприємстві-замовнику проекту.

Невисокі оцінки більшості експертів отримали такі напрями удосконалення та розвитку освітньої сфери, як:

-проведення моніторингу працевлаштування випускників навчальних закладів та створення відповідної інформаційної бази, яка буде містити дані відносно місць їх роботи після закінчення закладу освіти у розрізі конкретних спеціальностей, що дасть можливість визначити затребуваність підготовки за тими чи іншими освітніми програмами;

- розширення переліку баз виробничої та переддипломної практик для здобувачів освіти (експертним шляхом визначено недостатній вплив збільшення бази практичної підготовки на рівень подальшого працевлаштування випускників).

Одним із важливих, на нашу думку, шляхів нейтралізації загроз поширення неформальної зайнятості та збільшення безробіття $\epsilon$ розвиток нестандартних (інноваційних) форм зайнятості. Саме цьому питанню доцільно приділити значну увагу в процесі забезпечення соціальної безпеки на ринку праці та врахувати необхідність його вирішення при обгрунтуванні стратегічних пріоритетів державної політики у сфері соціально-трудових відносин. Крім того, актуальність вивчення можливостей розвитку таких форм зайнятості в Україні продиктована процесами діджиталізації та трансформаційним переходом до цифрової економіки, що спричиняє появу принципово нових професій, які є важливими на шляху економічних та суспільних змін. Доцільним $\epsilon$ визначення рис, які притаманні сучасній нестандартній зайнятості. Серед них варто відзначити: мобільність робочої сили з перегрупуванням зайнятих за галузями економіки та сферами діяльності; постійне підвищення професійно-кваліфікаційного рівня зайнятих, розвиток працюючого персоналу, оновлення його знань, умінь та навичок; впровадження інноваційних форм зайнятості та самозайнятості населення (фріланс, дистанційна зайнятість тощо); застосування гнучких форм зайнятості та організації робочого часу; формування інноваційного типу працівника, що характеризується готовністю до розробки та впровадження інновацій, швидкою адаптацією до змін, креативністю та новаторським мисленням, високим рівнем інтелекту.

Для працівників нетрадиційні форми зайнятості забезпечують цілий ряд можливостей та позитивних рис, серед яких: можливість досягнення балансу між роботою та сім'єю; гнучкість та раціоналізація використання робочого часу; можливість поєднання роботи з навчанням та іншими видами діяльності; саморозвиток та підвищення рівня своєї кваліфікації; інклюзивність (залучення до трудової діяльності осіб з обмеженою працездатністю та соціально вразливих категорій громадян). У той же час впровадження нестандартних форм зайнятості несе в собі додаткові переваги і для роботодавців, зокрема в контексті більшої гнучкості персоналу та можливостей швидкого заміщення тимчасово відсутніх працівників; залучення необхідної кількості персоналу для виконання термінових задач, в тому числі в умовах сезонних робіт та при форс-мажорних або непередбачуваних обставинах; можливості отримання більш високої результативності праці за рахунок наближення умов праці до потреб працівника тощо. Основні переваги впровадження нестандартних форм зайнятості для держави будуть виражатися у формалізації соціально-трудових відносин та зменшенні рівня безробіття (за рахунок створення додаткових робочих місць), а також зростанні економічної активності населення та бізнес-сфери, зростання купівельної спроможності, забезпечення економічної стабільності. 
Однак ці переваги матимуть місце лише за наявності відповідних умов щодо законодавчого закріплення, зваженої фіскальної політики та забезпечення соціального захисту працівників, які здійснюють свою трудову діяльність в рамках таких форм зайнятості.

Окрім характеристики перспективних напрямів щодо нейтралізації ключових загроз соціальній безпеці на ринку праці важливим в умовах динамічних змін економічного середовища та трансформації соціально-трудових відносин $\epsilon$ обгрунтування стратегічно важливих пріоритетів розвитку ринку праці в Україні. За підсумками експертного опитування щодо відповідних пріоритетних напрямів, можна зробити висновок про принципову важливість таких, що будуть, в свою чергу, сприяти формуванню стану захищеності соціальних інтересів населення на ринку праці, тобто забезпечувати його соціальну безпеку [11, С.18].:

-створення нових робочих місць та можливостей зайнятості для населення за рахунок розвитку економіки та подолання економічної кризи;

-реформування системи оплати праці та зниження диференціації доходів 3 урахуванням принципу соціальної справедливості з метою підвищення рівня трудових доходів та якості життя;

-детінізація ринку праці, що включає в себе формалізацію соціально-трудових відносин та виплату офіційної заробітної плати; регулювання нестандартних форм зайнятості населення;

-стимулювання молодіжної зайнятості та вирішення проблеми зростання безробіття серед молоді;

-розвиток освітньої сфери та забезпечення іï відповідності потребам ринку праці, зокрема в контексті співпраці сфер освіти та бізнесу; громадян;

-розвиток підприємництва та стимулювання підприємницької ініціативи

-зниження масштабів трудової еміграції;

-сприяння соціальному захисту працівників та дотриманню соціальних гарантій;

-удосконалення законодавчого регулювання ринку праці та його гармонізація із законодавством $\mathrm{CC}$;

-удосконалення фінансових та податкових механізмів стимулювання розвитку ринку праці (пільгові кредити, пільгове оподаткування);

-покращення умов праці за рахунок переоснащення виробництв та їх екологізації;

-розвиток інтелектуального потенціалу; праці.

-формування системи моніторингу та прогнозування тенденцій розвитку ринку

Зокрема, серед пріоритетних напрямів, які здійснюють позитивний вплив на ринок праці, на нашу думку, доцільно визначити ті, які сприятимуть забезпеченню як безпеки зайнятості, так і безпеки оплати праці. Крім того, доцільно визначити пріоритети розвитку ринку праці спільного впливу на стан його соціальної безпеки, серед яких: удосконалення законодавства у сфері праці та зайнятості та його узгодження iз нормативно-правовими документами $\mathrm{CC}$; удосконалення податкової та фінансової політики держави, що будуть спрямовані на стимулювання зайнятості та покращення фінансової спроможності суб'єктів господарювання; формування системи моніторингу та прогнозування ринку праці, що включатиме в себе вивчення тенденцій його розвитку стосовно попиту, пропозиції та ціни робочої сили, а також обгрунтування перспективних 
змін та факторів впливу, що їх формуватимуть. Врахування стратегічних пріоритетів розвитку ринку праці дозволяє сформувати механізм подолання ключових загроз соціальній безпеці на ринку праці, які стосуються неформальної зайнятості, зростання безробіття, зокрема молодіжного, зниження доходів та добробуту населення через низький рівень оплати праці.

В сучасних умовах функціонування ринку праці України, які характеризуються значним впливом не лише внутрішніх, а й зовнішніх факторів економічного середовища, важливим чинником формування соціальної безпеки на перспективу $є$ прогнозування майбутніх трендів та змін ситуації, що визначатиме вектор соціальноекономічного розвитку України, зокрема у питаннях праці й зайнятості. Саме тому важливою складовою оцінки перспектив нейтралізації основних в умовах трансформації економічного середовища загроз $є$ характеристика як позитивних, так і негативних тенденцій, які визначатимуть розвиток ринку праці України на перспективу найближчих 5-10 років. Так, серед тенденцій, що здійснюють позитивний вплив на розвиток ринку праці та стан його соціальної безпеки, відзначається поява нових професій та диверсифікація зайнятості, розвиток нестандартних форм зайнятості та самозайнятості населення, підприємництва та підприємницької активності, розвиток дуальної освіти та зростання частки ЗВО, що надають практичний досвід роботи під час навчання, розвиток неформальної освіти, скорочення неформальної зайнятості, підвищення рівня мобільності працездатного населення, посилення міжнародного співробітництва на ринку праці, зростання номінальної заробітної плати та мінімальних соціальних стандартів. У той же час спостерігається значна кількість негативних тенденцій, серед яких: посилення професійно-кваліфікаційних диспропорцій на ринку праці, загострення економічної кризи, зростання безробіття, високий рівень еміграції, зниження народжуваності та старіння нації, збереження низького рівня соціального захисту вразливих на ринку праці категорій населення, корупція, зниження рівня застосування людської праці та зростання автоматизованих систем управління виробничими процесами, зниження реальної заробітної плати, рівня та якості життя населення, висока плинність кадрів на підприємствах, збереження значної тінізації заробітної плати, погіршення якості трудового потенціалу, безробіття серед осіб старшого віку.

Окремої уваги заслуговують тенденції, що здійснюють як позитивний, так i негативний вплив на ринок праці. Зокрема, це діджиталізація бізнес-процесів, яка забезпечує оптимізацію робочого процесу та раціоналізацію режимів праці та відпочинку, але в той же час сприяє скороченню кількості працівників за рахунок цифрової переорієнтації діяльності. Також у числі тенденцій подвійного впливу збільшення кількості студентів, які працюють під час навчання. 3 одного боку це явище забезпечує можливість навчання працівника 3 урахуванням специфіки діяльності конкретного підприємства для роботодавця та отримання студентом практичного досвіду роботи, 3 іншого - нівелює значення отримання освіти у навчальних закладах.

Висновки. Враховуючи сучасний стан ринку праці в Україні та трансформаційні зміни, що мають місце у сфері соціально-трудових відносин, варто зазначити, що серед перспективних тенденцій розвитку сфери праці та зайнятості очікується переважання негативних факторів, які спричиняють загострення кризових явищ та поглиблення існуючих проблемних питань, що визначатимуть наявність значних загроз соціальній безпеці на ринку праці. Все це, в свою чергу, потребує обгрунтування цілого комплексу заходів законодавчого, соціально-економічного, 
організаційно-управлінського впливу, які доцільно врахувати в процесі формування дієвої державної та регіональної політики, стратегічних пріоритетів на рівні суб'єктів господарювання, покликаних забезпечити стан захищеності соціальних інтересів населення у питаннях зайнятості й оплати праці. Варто зазначити, що в умовах економічних трансформацій особливого значення набуває моніторинг тенденцій розвитку ринку праці та загроз його соціальній безпеці, який має базуватися на достовірній та точній інформації, а також об'єктивному та компетентному оцінюванні. Лише за умови проведення грунтовного аналізу стану соціальної безпеки на ринку праці та оцінки тенденцій його розвитку є можливим вчасне коригування державної політики та адаптація відповідних заходів до наявних змін.

\section{СПИСОК ВИКОРИСТАНИХ ДЖЕРЕЛ}

1. Hijzen A., Menyhert B. Measuring Labour Market Security and Assessing its Implications for Individual Well-Being. OECD: Social, Employment and Migration Working Papers. 2016. No. 175. OECD Publishing, Paris. URL: https://www.oecdilibrary.org/docserver/5jm58qvzd6s4-

en.pdf?expires $=1582033692 \& \mathrm{id}=\mathrm{id} \&$ accname $=$ guest $\&$ checksum $=6$ A7E7DA3E7903FA4B44 7A117CF3E5CA7

2. Crouch C. Flexibility and security in the labour market: An analysis of the governance of inequality. ZAF 43. 2010. P. 17-38. URL: https://doi.org/10.1007/s12651-010-0031-9 https://link.springer.com/article/10.1007/s12651-010-0031-9\#citeas

3. Wilthagen T. Managing social risks with transitional labour markets. In: Mosley, H., O’Reilly, J., Schömann, K. (eds.) Labour Markets, Gender and Institutional Change: Essays in Honour of Günther Schmid. 2002. pp. 264-289.

4. Грішнова О.А., Харазішвілі Ю.М. Якість життя в системі соціальної безпеки України: індикатори, рівень, загрози. Економіка України. 2018. №11-12. С. 157-180.

5. Shaulska L., Doronina O., Naumova M., Honcharuk N., Bondarevska K., Tomchuk O. Cross-country clustering of labor and education markets in the system of strategic economic management. REICE: Revista Electrónica De Investigación En Ciencias Económicas. 2020. Vol. 8, No. 16. P. 166-196. URL: https://doi.org/10.5377/ reice.v8i16.10681

6. Лісогор Л.С. Прогнозування розвитку ринку праці в Україні: проблеми та перспективи. Ринок праці та зайнятість населення. 2012. №1. С. 54-56.

7. Садова У.Я., Степура Т.М. Робочі місця як основа нової політики зайнятості й відтворення якості людського потенціалу в країні. Ринок праці та зайнятість населення. 2018. №2 (55). С.15-22

8. Сидорчук О.Г. Соціальна безпека: державне регулювання та організаційноекономічне забезпечення: монографія. Львів : ЛРІДУ НАДУ, 2018. 492 с.

9. Петяк Ю.Ф. Методика опитування експертів для виявлення факторів інформаційної безпеки мобільних пристроїв. Наукові записки. 2015. №1 (50). С. 23-29.

10. Бондаревська К.В. Загрози соціальній безпеці на рину праці України та шляхи їх нейтралізації: експертне опитвання. URL: https://docs.google.com/forms/d/18hQaICd8UsxX2fQLPFLCGZadvggejo_6FroSgVkiQuw/e dit\#response=ACYDBNgkVLDpRMuML2Gtp33-

28yX0oafUEXAR1f4DudZxhNYeiMgH3xozCK4tXXv4BldRws

11. Бондаревська К.В. Стратегія забезпечення соціальної безпеки на ринку праці України: автореф. дис. на здобуття наук. ступеня д-ра екон. наук : 08.00.07. Донецький національний університет імені Василя Стуса, Вінниця, 2021. 40 с. URL: https://abstracts.donnu.edu.ua/article/view/9648 
12. Про схвалення Концепції підготовки фахівців за дуальною формою здобуття освіти: Розпорядження КМУ від 19.09.2018 p. №660-P. URL: https://zakon.rada.gov.ua/laws/show/660-2018-\%D1\%80\#Text

\section{REFERENCES}

1. Hijzen A., Menyhert B. Measuring Labour Market Security and Assessing its Implications for Individual Well-Being. OECD: Social, Employment and Migration Working Papers. 2016. No. 175. OECD Publishing, Paris. URL: https://www.oecdilibrary.org/docserver/5jm58qvzd6s4-

en.pdf?expires $=1582033692 \&$ id=id\&accname $=$ guest $\&$ checksum $=6$ A7E7DA3E7903FA4B44 7A117CF3E5CA7

2. Crouch C. Flexibility and security in the labour market: An analysis of the governance of inequality. ZAF 43. 2010. P. 17-38. URL: https://doi.org/10.1007/s12651-010-0031-9 https://link.springer.com/article/10.1007/s12651-010-0031-9\#citeas

3. Wilthagen T. Managing social risks with transitional labour markets. In: Mosley, H., O’Reilly, J., Schömann, K. (eds.) Labour Markets, Gender and Institutional Change: Essays in Honour of Günther Schmid. 2002. pp. 264-289.

4. Hrishnova O.A., Kharazishvili Yu.M. Yakist zhyttia v systemi sotsialnoi bezpeky Ukrainy: indykatory, riven, zahrozy. Ekonomika Ukrainy. 2018. №11-12. S. 157-180.

5. Shaulska L., Doronina O., Naumova M., Honcharuk N., Bondarevska K., Tomchuk O. Cross-country clustering of labor and education markets in the system of strategic economic management. REICE: Revista Electrónica De Investigación En Ciencias Económicas. 2020. Vol. 8, No. 16. P. 166-196. URL: https://doi.org/10.5377/ reice.v8i16.10681.

6. Lisohor L.S. Prohnozuvannia rozvytku rynku pratsi v Ukraini: problemy ta perspektyvy. Rynok pratsi ta zainiatist naselennia. 2012. №1. S. 54-56.

7. Sadova U.Ia., Stepura T.M. Robochi mistsia yak osnova novoi polityky zainiatosti y vidtvorennia yakosti liudskoho potentsialu v kraini. Rynok pratsi ta zainiatist naselennia. 2018. №2 (55). S.15-22

8. Sydorchuk O.H. Sotsialna bezpeka: derzhavne rehuliuvannia ta orhanizatsiinoekonomichne zabezpechennia: monohrafiia. Lviv : LRIDU NADU, 2018. $492 \mathrm{~s}$.

9. Petiak Yu.F. Metodyka opytuvannia ekspertiv dlia vyiavlennia faktoriv informatsiinoi bezpeky mobilnykh prystroiv. Naukovi zapysky. 2015. №1 (50). S. 23-29.

10. Bondarevska K.V. Zahrozy sotsialnii bezpetsi na rynu pratsi Ukrainy ta shliakhy yikh neitralizatsii: ekspertne opytuvannia. URL: https://docs.google.com/forms/d/18hQaICd8UsxX2fQLPFLCGZadvggejo_6FroSgVkiQuw/e dit\#response=ACYDBNgkVLDpRMuML2Gtp33-

28yX0oafUEXAR1f4DudZxhNYeiMgH3xozCK4tXXv4BldRws

11. Bondarevska K.V. Stratehiia zabezpechennia sotsialnoi bezpeky na rynku pratsi Ukrainy: avtoref. dys. na zdobuttia nauk. stupenia d-ra ekon. nauk : 08.00.07. Donetskyi natsionalnyi universytet imeni Vasylia Stusa, Vinnytsia, 2021. 40 s. URL: https://abstracts.donnu.edu.ua/article/view/9648

12. Pro skhvalennia Kontseptsii pidhotovky fakhivtsiv za dualnoiu formoiu zdobuttia osvity: Rozporiadzhennia KMU vid 19.09.2018 r. №660-R. URL: https://zakon.rada.gov.ua/laws/show/660-2018-\%D1\%80\#Text 


\section{Бондаревская К.В.}

\section{КЛЮЧЕВЫЕ УГРОЗЫ И ПЕРСПЕКТИВЫ ПОДДЕРЖКИ СОЦИАЛЬНОЙ БЕЗОПАСНОСТИ НА РЫНКЕ ТРУДА УКРАИНЫ}

Статья посвящена оценке ключевых угроз социальной безопасности на рынке труда Украины и определению перспектив их нейтрализации в современных условиях. Приведены результаты авторского экспертного опроса «Угрозы социальной безопасности на рынке труда Украинь и пути их нейтрализации». С учетом результатов исследования определены тенденции, которые будут отражать функционирования рынка труда Украины на перспективу ближайших 5-10 лет. Обосновань стратегические приоритеты развития рынка труда в контексте обеспечения его соииальной безопасности по категориям безопасности занятости и безопасности оплаты труда.

Ключевые слова: сочиальная безопасность, рынок труда, занятость, оплата труда, угрозы социальной безопасности, безопасность занятости, безопасность оплаты труда.

\section{K. Bondarevska}

\section{KEY THREATS AND PROSPECTS OF SOCIAL SECURITY SUPPORT IN THE LABOR MARKET} OF UKRAINE

The article is devoted to the assessment of key threats to social security in the labor market of Ukraine and the definition of prospects for their neutralization in modern conditions. The results of the author's expert survey "Threats to social security in the labor market of Ukraine and ways to neutralize them" are presented. Taking into account the results of the study, trends have been identified that will reflect the functioning of the labor market of Ukraine for the next 5-10 years. The strategic priorities of the labor market development in the context of ensuring its social security by categories of employment security and salary security are substantiated. Key words: social security, labor market, employment, salary, threats to social security, employment security, salary security. 